\title{
Therapeutic study of Tephrosia purpurea (linn.) root extract on goat tapeworm with special reference to histopathological parameters
}

\author{
L.D. Ghaywat ${ }^{1}$, V.V. Bhavare ${ }^{2}$, S. S. Borgave ${ }^{3}$, R. V. Bhagde ${ }^{3}$ and L. M. Mahale ${ }^{4}$ \\ Department of Zoology, S. N. Arts, D. J. M. Commerce, B.N.S. Science College, \\ Savitribai Phule Pune University, Pune, Maharashtra-422605
}

Citation: Ghaywat, L.D., Bhavare, V.V., Borgave, S.S., Bhagde, R. V. and Mahale, L.M. 2021. Therapeutic study of Tephrosia purpurea (Linn.) root extract on goat tapeworm with special reference to histopathological study. J. Vet. Anim. Sci. 52(3): 286-291.

DOI: https://doi.org/10.51966/jvas.2021.52.3.286-291

Received: 01.05.2021

Accepted:21.05.2021

Published: 30.09 .2021

\section{Abstract}

Goat farming forms the backbone of the Indian livestock sector. The prevalence of helminth infection is one of the major problems which affects the milk and meat production of small ruminants. It causes diarrhea, anaemia, oedema, bottle jaw and reduce reproductive performance of animals. Anthelmintic resistance and drug residues in animal products like milk and meat are the results of indiscriminate use of anthelminthics by goat owners for helminth control. Herbal anthelminthics are effective alternatives without any harmful effects. The paper presents the anthelminthic potential of the root extract of Tephrosia purpurea (linn.) plant on common tapeworm of goat, Moniezia. The in vitro study showed that the anticestodal activity of T. purpurea (linn.) at $125 \mathrm{mg} / \mathrm{ml}$ dilution was comparable to that of albendazole. The histopathological study revealed very prominent shrinkage of scolex and suckers, tegument showed puff formation and was ruptured at the marginal position with irregular folds and crumbling of the segments. Longitudinal section of segment showed more marginal serrations indicating crumbling of the body segment as compared to albendazole, leading to the death of the worm.

Keywords: Anticestodal activity, in vitro study, histopathology, Moniezia, T. purpurea

Goat farming is one of the well-established livestock industry in India and different regions of world, and plays an important role in the economy of farmers. Goat products mainly meat and dairy have high consumer demand on account of specific taste, flavour, aroma, leanness and nutritive composition of fats, proteins and fatty acids. This meat is traditionally consumed all over the world (Boyazoglu et al., 2001). Goat products, such as milk and meat have great value in markets (Loewenstein, 1980; Webb, 2014). Goat farming is advantageous to the marginal and landless

1. Research Scholar, Affiliated to SPPU, Pune

2. Professor and Head (Corresponding author)-Mobile: +919284174492

Email: bhavare@sangamnercollege.edu.in

3. Assistant Professor

4. Assistant Professor, Department of Zoology, S.M.B.S.T College,

Sangamner, Ahmednagar District, India

Copyright: ( $) 2021$ Ghaywat et al. This is an open access article distributed under the terms of the Creative Commons Attribution 4.0 International License (http://creativecommons.org/licenses/by/4.0/), which permits unrestricted use, distribution, and reproduction in any medium, provided the original author and source are credited. 
farmers as this vocation does not require costly infra- structure and trained persons (Ghaywat et al., 2017). Gastrointestinal parasitic infection is commonly encountered in goat farming across the globe. The prevalence is 59.6 per cent in South Africa (Takalani et al., 2020), 75 per cent in Nigeria (Eke et al., 2019), 87.25 per cent in Nepal (Ghimire et al., 2019) and 96.22 per cent in the Philippines (Rupa et al., 2016). In India, the prevalence was around 68.75 percent in Mathura (Singh et al., 2013), 85.22 per cent in Chhattisgarh (Pathak et al., 2008), 92.4 per cent in Shillong and Meghalaya (Bandyopadhyay et al., 2010) and 62.75 per cent in Ahmednagar district (Sutar et al., 2010).

Gastrointestinalinfection is associated with reduced milk and meat production and affects the health of goats by causing diarrhea, anaemia, bottle jaw, oedema and reduced productivity (Sutar, 2010). Infection with the cestode, Moniezia expansa, leads to inappetence, diarrhoea and chronic loss of weight (Yadav et al., 2019). To control the gastrointestinal parasite goat owners frequently resort to chemical dewormers such as albendazole, a broad spectrum anthelmintic of benzimidazole class. Albendazole causes degenerative alteration in the tegument and endoplasmic reticulum, while in the mitochondria it affects the production of ATP ultimately leading to immobilization and death of the parasite (Albendazole Drug bank -https:// go.drugbank.com/drugs/DB00518). Mutations in the target site genes lead to drug resistance and hence alternative control strategies have to be adopted. Some plant bio active compounds are effective against this parasite besides being safe and eco-friendly (Gives et al., 2012). Tribal people use many herbal medicines for themselves and their domestic animals (Iqbal et al., 2003). Tephrosia purpurea commonly called Sarpunkha or Unhali in Marathi is used to cure many diseases of human beings. It is also used in animals to control gastrointestinal parasites (Baranwal et al., 2014). It is a tropical leguminous shrub that grows to a height of 40 $80 \mathrm{~cm}$. The plant has pinnate leaves. Flowers are pink or purple in colour, root is a long stout taproot having slender branches. It has a characteristic odor, is yellow to brownish in colour and has an intricate bitter taste.
Phytochemicals present in roots are tannins, tephrosin, isotephrosin, phytosterols, purpurin, deguelin, rotenone, glycosides isolonchocarpin (Baranwal et al., 2014). In these circumstances, an invitro study was done to assess the anticestodal efficacy of the root extract of Tephrosia purpurea, the medicinal plant commonly used by the tribal people in Akole and Sangamner talukas of Ahmednagar District of Maharashtra State.

\section{Materials and methods}

\section{Collection of plant materials}

As per the reference of local goat keepers of Akole Taluka, the plant material was collected from the study area during the month of November. The plant was identified and authenticated by a taxonomist from Botany department of Sangamner College. The roots were collected by uprooting the plants. The aerial part of the root was discarded. Roots were brought to the laboratory, washed with distilled water, cut into small pieces and shade dried. Later it was dried in the oven at $37^{\circ} \mathrm{C}$ for two days and powdered by grinding in a mixer.

\section{Preparation of plant extract}

Tephrosia purpurea powder (50 gm) was used and methanolic extract of the plant root powder was prepared by using Soxhlet apparatus. The extract was then concentrated in Rota evaporator at $40^{\circ} \mathrm{C}$ in reduced pressure, air dried and extract was used for further treatment.

\section{Collection of parasites}

The intestines of slaughtered goats were collected from the local abattoirs in and around Sangamner, in the plastic container and immediately brought to the laboratory. The intestine was further dissected in PBS solution and tapeworms were collected from the lumen of the small intestine. The collected worms were thoroughly washed in PBS (Phosphate buffer solution) and then transferred to a petri plate containing Hank's solution along with two drop of 1 per cent DMSO added as a carrier agent. Samples were identified based on morphologic parameters. 


\section{In vitro anticestodal activity evaluation}

The worms were collected from the intestine and identified as Moniezia. The anticestodal test was performed in the Petri plates of equal volume. Four concentration of the plant extract were used. Five worms were released in each Petri plate in each set of concentration, in triplicate, during experimental setup.

The experimental set up included three groups: Group I with four sets of concentrations (50, 75, 100, $125 \mathrm{mg} / \mathrm{ml}$ of Hank's solution) of Tephrosia purpurea root methanolic extract; Group II with $10 \mathrm{mg} / \mathrm{ml}$ Albendazole as a positive control; Group III with Hank's solution as a negative control. In each case the extract was dissolved in few drops of one per cent DMSO solution as a carrier. The motility of worms was observed frequently at an interval of half an hour till the death of the parasite and the time of paralysis and death was noted. The death was again confirmed by testing the motility of the worm in lukewarm solution for $30 \mathrm{~min}$. Histopathological study was done by observing the effect of the extract on the scolex and integument of normal and treated worms and the results were compared.

\section{Data analysis}

Data on paralysis and death was noted and analysed by using SPSS, 2015 version. The data obtained from negative control, positive control and treatment groups were analysed with one - way ANOVA test. Results were considered significant if $p$ value was less than 0.05 at 95 per cent confidence intervals.

\section{Results and discussion}

\section{In vitro anticestodal activity}

The invitro assay showed that the methanolic extract of $T$. purpurea produced anticestodal activity comparable with that of the synthetic drug Albendazole (Albendazole oral suspension containing $25 \mathrm{mg} / \mathrm{ml}$ Albendazole IP recommended for sheep, goat and poultry). The effective concentration of albendazole was $10 \mathrm{mg} / \mathrm{ml}$ demonstrating paralysis and death at minimum period of $1.43 \pm 0.14 \mathrm{~h}$ and $2.3 \pm 0.27 \mathrm{~h}$, respectively. Similarly, the highest concentration of methanolic extract $(125 \mathrm{mg} / \mathrm{ml})$ was found to be most effective showing minimum time of $1.29 \pm 0.17 \mathrm{~h}$ and $2.63 \pm 0.36 \mathrm{~h}$ for paralysis and death, respectively. The result revealed that the methanolic extract of T. purpurea , at $125 \mathrm{mg} /$ $\mathrm{ml}$, showed effective anticestodal activity comparable to albendazole (Table 1). Further the histopathological study was done to see the effect of extract on the various parts of the worm

\section{Histopathological evaluation}

Histopathological study of the whole mount and longitudinal section of normal and treated worms were done. The effect of albendazole and herbal extract was observed under microscope. The comparative study

Table 1. Mean mortality time of the control and treated Moniezia

\begin{tabular}{|c|c|c|c|}
\hline Treatment & \multicolumn{3}{|c|}{ Mean mortality time of worm (Mean \pm SD) } \\
\hline & & Paralysis & Death \\
\hline $\begin{array}{l}\text { Hanks solution + } \\
2 \text { drops of DMSO }\end{array}$ & & $17.7 \pm 0.74$ & $26.1 \pm 2.92$ \\
\hline Albendazole & $1 \mathrm{mg} / \mathrm{ml}$ & $7.8 \pm 0.51$ & $10.2 \pm 0.57$ \\
\hline & $5 \mathrm{mg} / \mathrm{ml}$ & $4.8 \pm 0.51$ & $7.7 \pm 0.27$ \\
\hline & $10 \mathrm{mg} / \mathrm{ml}$ & $1.43 \pm 014$ & $2.3 \pm 0.27$ \\
\hline Methanol Extract & $10 \mathrm{mg} / \mathrm{ml}$ & $10.5 \pm 0.31$ & $13.5 \pm 1.74$ \\
\hline & $50 \mathrm{mg} / \mathrm{ml}$ & $7.5 \pm 0.31$ & $11.1 \pm 0.22$ \\
\hline & $75 \mathrm{mg} / \mathrm{ml}$ & $5.5 \pm 0.8$ & $10.6 \pm 0.65$ \\
\hline & $100 \mathrm{mg} / \mathrm{ml}$ & $7.9 \pm 1.93$ & $7.9 \pm 0.41$ \\
\hline & $125 \mathrm{mg} / \mathrm{ml}$ & $1.29 \pm 0.17$ & $2.63 \pm 0.36$ \\
\hline
\end{tabular}


of the effect on normal, albendazole treated and T. purpurea root extract treated worms is shown in the Fig. I. When normal PBS solution was used, the scolex with four suckers were seen well in position and structure, tegument did not show any morphological changes at the margin and body surface. In the case of the Albendazole treated group, folds on scolex with shrinkage of the suckers were seen and the tegument showed slight shrinkage while the histological section (L.S) revealed shrinkage of the body segment with serrations on the margins (Fig 2.1 to 2.3). In the case of the group treated with the methanolic extract of Tephrosia purpurea, very prominent shrinkage of scolex and suckers, with puff formation of tegument, rupture at the marginal position on body surface, irregular folds and crumbling of the segment were observed. Histological section (L.S) showed more marginal serrations indicating the crumbling of the body segment which was comparable with the changes seen

\begin{tabular}{|c|c|c|}
\hline Normal in Hanks solution & Albendazole10mg/ml & $\begin{array}{c}\text { Root extract treatment } \\
125 \mathrm{mg} / \mathrm{ml}\end{array}$ \\
\hline $\mathrm{S}$ & & \\
$\mathrm{N}$ & $\mathrm{S}$ & \\
\hline
\end{tabular}

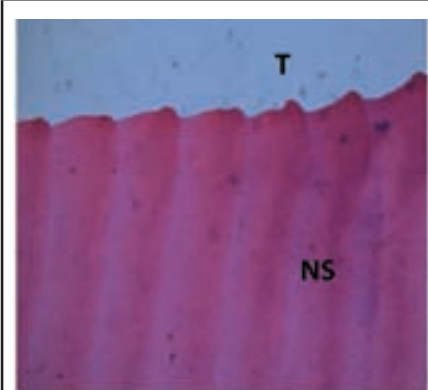

Fig -1.2

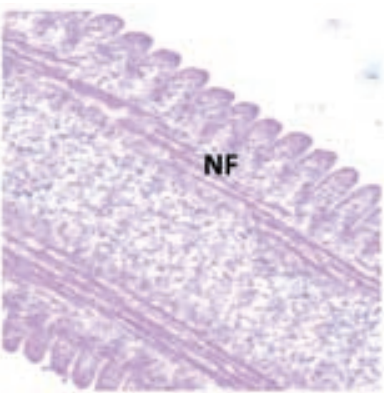

Fig -1.3

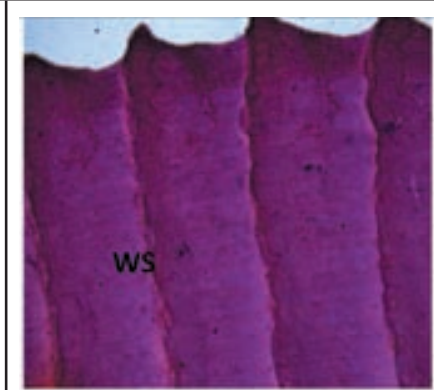

Fig $-\mathbf{2 . 2}$

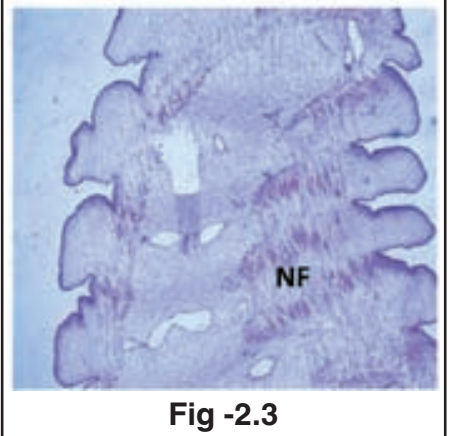

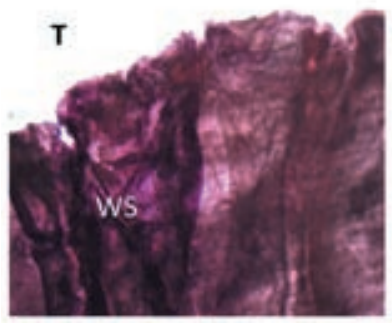

Fig $\mathbf{- 3 . 2}$

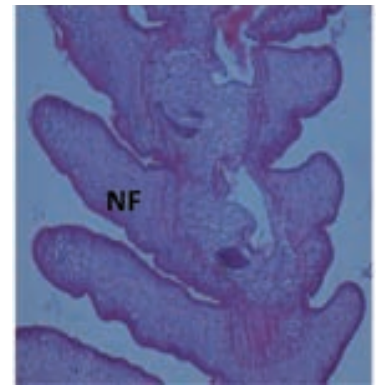

Fig -3.3

Fig. 1 - 3. Comparative histopathological features of Moniezia - Scolex and Mature
S-sucker
T- tegument
W-Wrinkles
NS- Normal Segment WS-Wrinkled Segment
$\mathrm{P}$ - Parenchyma NF-Nerve Fiber $\mathrm{N}$ - Neck 
in the group that was exposed to albendazole (Fig. 3.1 to 3.3).

Tapeworm infection is one of the most common problem encountered with respect to the sheep, goat and cattle, affecting the production of milk and meat. Herbal anthelminthics are attractive alternatives in this respect. A medicinal plant, T. purpurea, used by tribal communities has been reported to possess antimicrobial, anti-diabetic, antileishmanial and antibacterial activities (Sharma et al., 2013). In this study, the results with the root extract of $T$. purpurea showed effective anticestodal activity. Similar results against earthworm and tapeworm were also seen on using leaf extract of T. purpurea by Patel et al. (2011). These results are also in agreement with the findings of Manjula et al. (2013), who reported the efficacy of leaf extracts against earthworms. The histopathological study was conducted to see the effect of treatment on the scolex and mature segments. It showed that the plant extract caused higher level of destruction of the integument, parenchyma tissue that led to a crumbling of the scolex and segment which may lead to the death of the worm. Phytochemical screening of the root extract, showed that there are some secondary metabolites like phytosterols, glycosides, flavonoids, tannins, phenol etc. (Baranwal et al., 2014), of which . tannin acts as an anthelminthic agent. Further in vivo trials are needed to explore the use of these drugs on commercial scale for cestode control.

\section{Conclusion}

Medicinal plants are natural sources of metabolites that have antibacterial, antiviral, anti-diuretic properties and can be used as herbal medicines. The use of plants like $T$. purpurea as an anthelmintic drug can be a good alternative for the chemical drugs. The study on root extract of $T$. purpurea to see its invitro anticestodal activity would serve as a preliminary work to derive the herbal drug for future use.

\section{Acknowledgement}

The authors deeply acknowledge DST - FIST, Savitribai Phule, Pune University and the Management of the College, for providing all the technical support and infrastructure for conducting the research.

\section{Conflict of interest}

The authors declare that they have no conflict of interest.

\section{References}

Albendazole Drug bank,https://go.drugbank. com/drugs/DB00518 [Accessed on 01,May,2021]

Bandyopadhyay, S., Devi, P., Bera, A., Bandyopadhyay, S. and Bhattacharya, D. 2010. Prevalence of gastrointestinal parasite in goats in Shillong, Meghalaya, India. Webmed Cent. Parasitol. 1(9): 1-10

Baranwal, A., Avijit, M., Chakraborthy, G.S. and Seema, G. 2014. Phytopharmacological uses of Tephrosia Purpurea - A Review. Pharmacophore, 5 (4): 658-665.

Boyazoglu, J. and Morand-Fehr, P. 2001. Mediterranean dairy sheep and goat products and their quality. A critical review. Small Rumin. Res. 40 (1):1-11.

Eke, S.S., Omalu, I. C. J., Ochaguba, J. E., Urama, A. C., Hassan, S. C., Otuu C. A. and Okafor I. D. 2019. Prevalence of gastrointestinal parasites of sheep and goats slaughtered in Minna Modern Abattoir, Niger State, Nigeria. J Anim. Sci. Vet. Med., 4(2): 65-70.

Ghaywat, L.D., Shaikh S.A. and Bhavare V.V. 2017. Goat rearing -as the emerging source of economy in rural area. SRJIS. 6 (34): 1047-104.

Ghimire, T. R. and Bhattaraj, N. 2019. A survey of gastrointestinal parasites of goats in a goat market in Kathmandu, Nepal. $J$ Parasit Dis. 43(4): 686-695.

Gives, P.M., Arellano,M. E.L., Hernández, E.L. and Marcelino, L.A. 2012. Plant Extracts: A Potential Tool for Controlling Animal Parasitic Nematodes.The Biosphere Intech open. Available : https://www. 
intechopen.com/chapters/31343[ 01,May, 2021]

Iqbal, Z., Akhtar,M.S., Zia-Ud-Din Sindhu, Khan $\mathrm{N}$ and M. Abdul. 2003. Review: Herbal De wormers in Livestock - A Traditional Therapy, Int. J.Agric. Biol. 5(2): 199-206.

Manjula, R. R., Spandana, U., Joshi, A.T. and Sudheer, M. 2013. Invitro anthelminthic activity of aqueous and methanolic leaf extract of Tephrosia purpurea Linn., IJRPC. 3(1): 12-14.

Morrison, L., Stephen, J.S., Harold, M.B. and Joseph F. F. 1980. Research on Goat Milk Products: A Review. J. Dairy Sci. 63(10): 1631-1648.

Patel, A.V Patel, A. V. Bharadiya P.D. and Patel N. M. 2011. A study on evaluation of anthelminthic activity of leaves extract of T. purpurea (Linn). Invented Rap. Ethnopharm. 3: 1-2

Pathak A. K. and Pal, S. 2008. Seasonal Prevalence of Gastrointestinal Parasites in Goats from durg district of Chhattisgarh. Vet. World. 1(5): 136-137.

Rajesh, S., Sidharth M., Sanjeev K. and Deepa, K. 2013. Tephrosia purpurea-A Magical Herb with Blessings in Human Biological System. Int $J$ Recent Adv Pharm Res. 3(3): 12-22
Rupa, A.P. M and Portugaliza H.P. 2016 Prevalence and risk factors associated with gastrointestinal nematode infection in goats raised in Baybay city, Leyte, Philippines. Vet. World. 9(7): 728-734.

Singh V., Varshney P., Dash S. K. and Lal H. P. 2013. Prevalence of gastrointestinal parasites in sheep and goats in and around Mathura, India. Vet. World. 6(5):260-262.

Sutar A. U., Kengar S. B., Patil S. S. and Khan M. R. 2010. Prevalence of Gastrointestinal Parasites in Goats of Ahmednagar district of Maharashtra, Vet. World. 3(10): 456-457.

Takalani J. M., Khathutshelo, A. N. and Bohani M. 2020. Prevalence of gastrointestinal parasites in communal goats from different agro-ecological zones of South Africa, Vet. World. 13(1): 26-32.

Webb, E.C. 2014. Goat meat production, composition and quality. Anim. Front. 4(4): 33-37

YadavS., PatelP.K., Deepak,D., NaveenK.V.and Dixit S.K. 2019. Medical Management of Moniezia expansa infection in buck: A case report, J. Pharmacog. Phytochem. 8(1):1686-1688 